\title{
СИНТЕЗ СТРУКТУРИ ЕНЕРГОЗБЕРІГАЮЧОЇ СИСТЕМИ ПІДТРИМКИ ПРИЙНЯТТЯ РІШЕНЬ ДЛЯ ЛОКОМОТИВНИХ БРИГАД
}

\author{
Д.т.н. О. Б. Бабанін, д.т.н Д. В. Ломотько, к. т. н. О. М. Горобченко
}

\section{СИНТЕЗ СТРУКТУРЫ ЭНЕРГОЗБЕРЕГАЮЩЕЙ СИСТЕМЫ ПОДДЕРЖКИ ПРИНЯТИЯ РЕШЕНИЙ ДЛЯ ЛОКОМОТИВНЫХ БРИГАД}

\section{Д.т.н. А. Б. Бабанин, Д.т.н Д. В. Ломотько, к. т. Н. А. Н. Горобченко \\ SYNTHESIS OF STRUCTURE OF ENERGY-SAVING DECISION SUPPORT SYSTEM FOR LOCOMOTIVE CREWS.}

Doct. of techn. sciences A. B. Babanin, doct. of techn. sciences D. V. Lomotko, PhD A. N. Gorobchenko

Розглянуто питання створення енергозберігаючої структури системи підтримки прийняття рішень. В результаті аналізу існуючих типів інтелектуальних систем, ̈̈х ієрархій та алгоритмів, враховуючи умови роботи локомотивних бригад та залізничного транспорту в иілому, розроблені параметри проектної системи. Особливістю ї̈ $\epsilon$ можливість оцінки безпеки руху при виробленні рішень.

Ключові слова: локомотивна бригада, керування поїздм, інтелектуальна система, прийняття рішень.

Рассмотрены вопросы создания энергосберегающей структуры системы поддержки принятия решений. В результате анализа существующих типов интеллектуальных систем, их иерархий $u$ алгоритмов, учитывая условия работы локомотивных бригад $u$ железнодорожного транспорта в целом, разработаны параметры проектируемой интеллектуальной системы. Особенностью ее является возможность оценки безопасности движения при выработке решений.

Ключевые слова: локомотивная бригада, управление поездом, интеллектуальная система, принятие решений.

Defined characteristics of the DSS for locomotive crews. Synthesis structure DSS performed in three stages: determining the number of levels and units of the system, the distribution system functions through the levels, rationale for the use of technical means. A distinctive feature is the availability of its subsystems assess the complexity of emergency situations, predicting the quality of decisions, communicate with the server of the railway, the control environment. An analysis of existing types of intelligent systems and their hierarchies and algorithms, considering the conditions of work of locomotive crews and railway transport as a whole, the projected parameters developed intellectual system. It is determined that the system consists of two levels - level and the level of the railway locomotive. Skill distribution system functions through the levels and justified the choice of means. The purpose of the system is to develop management solutions locomotive that will ensure sustainable use of the rolling stock in the current train situation. A special feature is the ability to assess its safety when making decisions.

Keywords: locomotive crew, train control, intelligent system, decision making.

Постановка проблеми в загальному завдань 3 управління транспортними вигляді. Ефективна та безпечна робота процесами забезпечує можливість створення залізничного транспорту багато в чому систем підтримки прийняття рішень (СППР) залежить від вірності та оперативності для локомотивних бригад щодо забезпечення рішень, що приймають працівники залізниць безпеки руху при керуванні поїздом та на різних рівнях. Розвиток сучасних підвищення ефективності використання інформаційних технологій , методології локомотивів. Розробка цієї системи являє моделювання складних систем і вирішення собою актуальну, досить складну проблему, 
пов'язану 3 продукцією обгрунтованих рішень в умовах обмеження часу, неповної визначеності ряду факторів, у тому числі і переваг особи, що приймає рішення . Успішне вирішення даної проблеми може бути забезпечене тільки при ефективному поєднанні досвіду, знань, інтуїції та вміння людини приймати обгрунтовані рішення 3 сучасними математичними методами рішення завдань i імітаційним моделюванням розглянутих процесів.

Аналіз досліджень та публікацій. Відомо, що головними проблемами, розв'язуваними при створенні таких систем, $€$ зіставлення описів станів об'єкта прийняття рішень (об'єкта керування) 3 умовами істинності продукцій, а також визначення послідовності перегляду та аналізу продукцій при виводі рішень [1]. В роботі [2] запропоновано системний підхід до створення СППР та методологія, що базується на ідеї накопичення знань в комп'ютерній формі баз знань 3 подальшим ïх використанням для прийняття рішень. Опис поточного стану об'єкта керування представляється у вигляді нечіткої ситуації [3]. Інтерактивна процедура прийняття рішення за допомогою СППР представляє собою циклічний процес взаємодії людини та комп'ютера. В ньому є такі елементи: аналіз і постановка завдання для комп'ютера та фаза пошуку рішення. СППР виконують наступні функції [4]:

1. Допомагають людині оцінити обстановку, обрати критерії та оцінити їх відносну важливість.

2. Генерують можливі сценарії дій.

3. Виконують оцінку сценаріїв, обираючи найкращий.

4. Забезпечують постійний обмін інформацією о процесі прийняття рішення і допомагають узгоджувати групові рішення.

5. Моделюють рішення, що приймаються.

6. Здійснюють динамічний комп'ютерний аналіз можливих наслідків рішень.

7. Виконують збирання даних при результати реалізації прийнятих рішень.

8. На основі аналізу результатів прийнятих рішень і оцінки їх ефективності виконують донавчання.

За характером розподіленості СППР можуть бути розподілені і сконцентровані. Сконцентровані (локальні) СППР включають в себе одну систему, встановлену на одній
EOM, вони допомагають одній особі, що приймає рішення (ОПР) [5]. Просторово та функціонально розподілені СППР складаються 3 локальних СППР, розташованих в зв'язаних між собою вузлах обчислювальної мережі, кожен з яких може незалежно вирішувати свої завдання, але для вирішення загальної проблеми жодна 3 них не має достатніх знань, інформації та ресурсів. Загальну проблему вони можуть вирішувати тільки сукупно.

Постановка задачі. У нашому випадку постає завдання синтезу структури СППР для локомотивних бригад, щоб забезпечувала максимальну ефективність 3 точки зору енергозбереження та безпеки руху. Цю систему на першому етапі впровадження можна вважати локальною (встановленою на локомотиві для використання одним машиністом). Однак в подальшому, при достатньому розвитку бортових систем потрібно переходити до наступного етапу - створення розподіленої системи, що буде вміщувати бортові локомотивні СППР, засоби зв'язку, серверну частину, загальну базу знань.

Викладення основного матеріалу. Архітектури реальних систем штучного інтелекту можуть бути найрізноманітнішими. Для реалізації подібних систем розробляються спеціальні інструментальні програмні засоби. Ці засоби припускають певну технологію створення систем. Подібна технологія включає ряд великих етапів, типовими 3 яких $\epsilon$ наступні: вибір архітектури системи;

локальних цілей, що стоять перед кожним 3 них; принципів взаємодії й виробітки глобального рішення);

вивчення властивостей і поводження середовища, з яким прийдеться мати справу системі, і подання цих знань у вигляді неформальної онтології. Цей етап часто називають добуванням знань про середовище;

подання глобальних (доступних всім системам) i локальних знань (доступних окремим системам), отриманих на етапі добування знань, формальною мовою якогось обчислення у вигляді формальних глобальної та локальної онтологій. Цей етап часто називають формалізацією; 
вибір стратегії висновку, на основі використання якої система буде досягати поставленої перед нею мети;

розробка програми і апаратури, що реалізує систему. Цей етап іноді називають реалізацією.

Розподілена СППР для локомотивних бригад являє собою складну систему 3 комплексною взаємодією розташованих на великій відстані бортових локомотивних систем i якість іiі організації визначає ефективність системи в цілому.

Якщо $\Pi-$ множина можливих принципів $n \in \Pi$ побудування системи і iï елементів; $F$ - множина взаємозв'язаних функцій, що виконуються системою; $A$ множина взаємозв'язаних бортових локомотивних систем, тоді згідно до [6] задача синтезу раціональної структури розподіленої СППР полягає в визначенні множини принципів побудови ( $n \in \epsilon \quad \Pi)$, множини функцій, що виконуються системою $(f \in F(n))$, множини елементів, здатних реалізувати обрані принципи i виконати функції ( $\overline{\mathrm{A}} \in A$ ), а також оптимального відображення елементів множини $f$ на елементи множини $\overline{\mathrm{A}}$. При виборі варіанта структури локомотивної системи можливі два види відображення $f \rightarrow \overline{\mathrm{A}}:$ перший, коли кожна задача виконується лише одним 3 декількох можливих вузлів системи, і другий, коли задача виконується декількома вузлами системи. Вимоги до локомотивних систем потребують реалізації за другим варіантом.

На практиці для вирішення задачі створення оптимальної структури розподіленої СППР широко застосовується агрегативно-декомпозитний метод [6], котрий включає два етапи: декомпозицію задачі на низку часткових задач i агрегування часткових результатів. Таким чином, під проектуванням оптимальної структури СППР для локомотивних бригад будемо розуміти процес поступового рішення задач синтезу основних елементів $\mathrm{i}$ частин системи (рисунок 1 ).

В результаті аналізу існуючих типів інтелектуальних систем, ієрархій та алгоритмів їх роботи, враховуючи умови роботи локомотивних бригад та залізничного транспорту в цілому, розроблені параметри інтелектуальної СППР (зведені до таблиці 1)

Таблиця 1 - Характеристики СППР для локомотивних бригад

\begin{tabular}{|c|c|c|}
\hline $\begin{array}{l}\text { Ознака, за якою } \\
\text { класифікується } \\
\text { СППР }\end{array}$ & $\begin{array}{l}\text { Найменування } \\
\text { параметру }\end{array}$ & Описання параметру \\
\hline $\begin{array}{l}\text { Tип структуро- } \\
\text { ваності вирішу-ваних } \\
\text { проблем }\end{array}$ & Слабоструктуровані & $\begin{array}{l}\text { Вихідні параметри містять як кількісні, } \\
\text { гак і якісні елементи }\end{array}$ \\
\hline $\begin{array}{l}\text { Характер } \\
\text { розподіленості }\end{array}$ & $\begin{array}{l}\text { Просторово } \\
\text { функціонально } \\
\text { розподілені }\end{array}$ & $\begin{array}{l}\text { Складаються } 3 \text { окремих зв'язаних між } \\
\text { собою локальних локомотивних СППР, } \\
\text { що можуть вирішити загальну проблему } \\
\text { гільки разом }\end{array}$ \\
\hline $\begin{array}{l}\text { Характер } \quad \text { оцінки } \\
\text { результатов рішення }\end{array}$ & $\begin{array}{l}\text { Рішення, } \\
\text { об’єктивно } \\
\text { оцінюються }\end{array}$ & $\begin{array}{l}\text { Оцінка результату основана на явно } \\
\text { заданих критеріях, що визначають } \\
\text { досягнення цілі: витрати палива, } \\
\text { міжремонтний пробіг, показники безпеки } \\
\text { руху тощо. }\end{array}$ \\
\hline $\begin{array}{l}\text { Характер ситуації, в } \\
\text { якій ОПР приймає } \\
\text { рішення }\end{array}$ & Екстремальні ситуації & $\begin{array}{l}\text { Прийняття рішення по керуванню } \\
\text { поїздом характеризується дефіцитом часу } \\
\text { та обстановкою, що швидко змінюється. }\end{array}$ \\
\hline $\begin{array}{l}\text { Тип комп’ютерного } \\
\text { аналіза ситуацій }\end{array}$ & Динамічний & $\begin{array}{l}\text { Мається набір сценаріїв по керуванню } \\
\text { поїздом, } 3 \text { якого обирається один } \\
\text { найбільш ефективний на даний момент }\end{array}$ \\
\hline
\end{tabular}


ETAП 1 Визначення числа рівнів ієрархії і вузлів системи

Характеристики спПР, чо враховуються при визначенні ієрархіі:

ціль сппР:забезпечити раціональне використання локомотивів в межах окремої залізниці.

Функції CппР 1) наповнення бази знань інформацією про раціональні режими ведення поїздів, дії локомотивних бригад в нестандартних ситуаціях, порядок керування декількома поїздами на ділянці; 2) оцінка ефективності експлуатації локомотивів; 3) оцінка поточної поїзної обстановки; 4) прогнозування корисності рішень, що виробляються; 5) оцінка технічного стану поїзда і локомотива; 6) визначення поточного рівня безпеки руху поїзда; 7) представлення раціонального рішення у прийнятній для ОПР формі.

Інформаційні потоки СППР:сервер СППРзалізниці -бортова СППР, глобальна система орієнтування-бортова СППР, бортова СППР-локомотивна бригада, бортова система діагностики-бортова СППР

\begin{tabular}{|l|l|}
\hline $\begin{array}{l}\text { Визначення числа рівнів } \\
\text { ієрархіі }\end{array}$ & $\begin{array}{l}\text { Іерархія СпПР дворівнева: 1- рівень залізниці; 2- } \\
\text { рівень локомотива } \\
\text { Кількість вузлів відповідає експлуатаційному парку } \\
\text { локомотивів }\end{array}$ \\
\hline
\end{tabular}

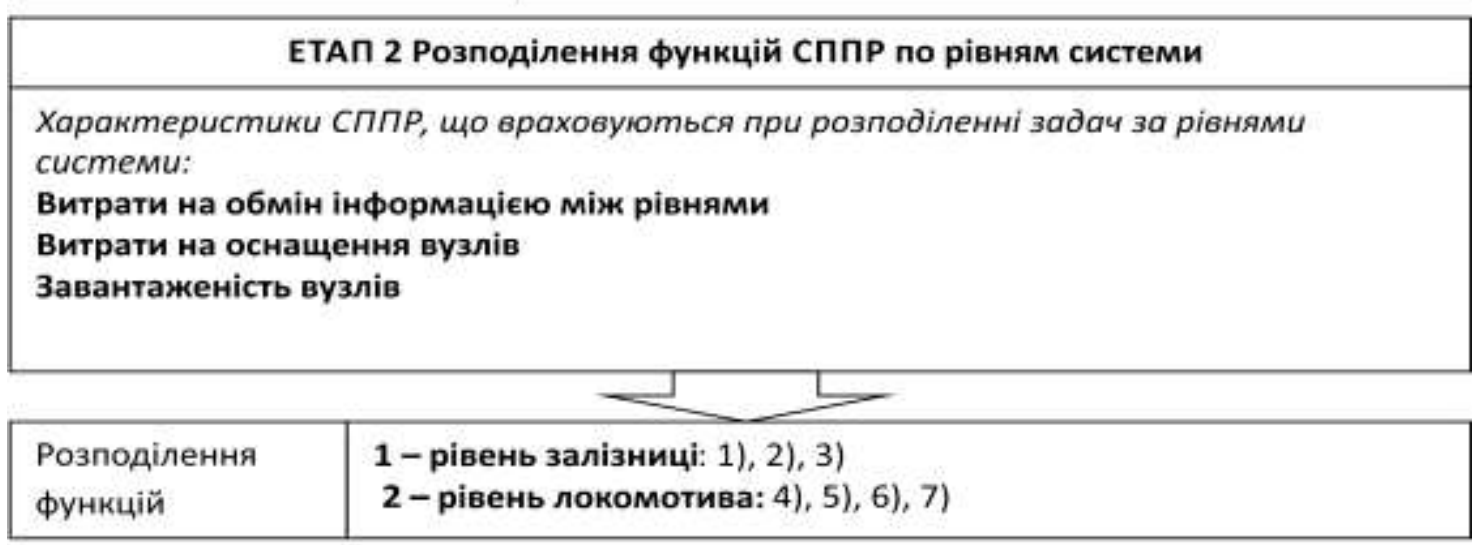

\begin{tabular}{|c|c|}
\hline \multicolumn{2}{|r|}{ ЕТАП 3 Вибір технічних засобів для вузлів системи } \\
\hline \multicolumn{2}{|c|}{$\begin{array}{l}\text { Характеристики СППР, що враховуються при виборі технічних засобів: } \\
\text { Функції СпПР } \\
\text { Параметри основних алгоритмів СППР } \\
\text { Експлуатаційні вимоги до СППР }\end{array}$} \\
\hline $\begin{array}{l}\text { Вибір } \\
\text { засобів }\end{array}$ & $\begin{array}{l}\text { 1 - рівень залізниці: сервер стандартної конфігурації, система } \\
\text { зв'язку не нижче } 3 \mathrm{G} \text {; } \\
\text { 2- рівень локомотива: сукупність датчиків, система визначення } \\
\text { положення поїзду, приймач-передавач сигналу, бортова ЕОМ, } \\
\text { система вводу-виведення інформації }\end{array}$ \\
\hline
\end{tabular}

Рис. 1. Етапи синтеза структури СППР

Наведені на рисунку 1 задачі вирішуються ітераційно в силу їх взаємозв'язку, неповноти вихідних даних i необхідності корегування отриманих рішень.
СППР сприймає зовнішню поїзну обстановку за допомогою датчиків $\mathrm{x}_{1}, \ldots \ldots$. $\mathrm{x}_{\mathrm{m}}$ i впливає на неї за допомогою виконавчих органів $\mathrm{Z}_{1}, \ldots \ldots \ldots . . . \mathrm{Z}_{\mathrm{m}}$. 
Поводження інтелектуальної системи складається в переробці сприйнять у реакції. Ця переробка здійснюється за допомогою спеціального вирішувача, що функціонує на основі закладених у нього знань.

Спрощений принцип роботи системи показаний на рисунку 2. СППР одержує повідомлення від системи збору інформації про параметри ведення поїзда. Завданням іï $\epsilon$ аналіз різних ситуацій під час руху на основі цих повідомлень i видача машиністу результатів цього аналізу. Машиніст оцінюючи результати роботи СППР, а також своє сприйняття ситуації, виконує керуючі впливи на рух поїзда.

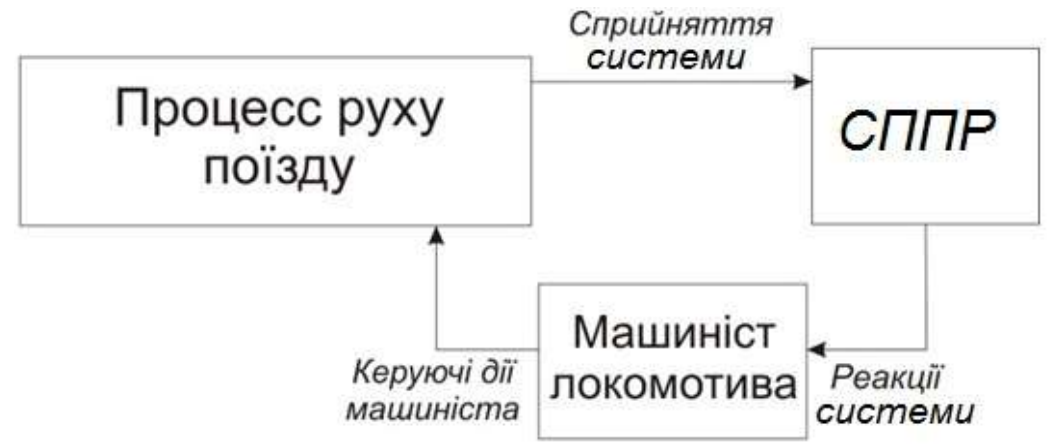

Рис. 2. Принцип роботи бортової локомотивної СППР

Пропонується локомотивної СППР, що наведена на рисунку 3.

Людино-машинний призначений для забезпечення взасмоді локомотивних бригад та обслуговуючого персоналу з системою. Тут присутні системи введення та системи відображення інформації.

Нечіткий класифікатор необхідний для моніторингу, розпізнавання та передачі в систему образів ситуацій, в яких знаходиться поїзд під час руху. Інформація до нього надходить 3 інтерфейсної частини СППР, призначення якої перетворити фізичні сигнали різних контрольованих величин у прийнятну для сприйняття системою форму.

Підсистема логічного висновку, використовуючи формалізовані знання, виробляє рекомендації 3 керування локомотивом. Тут реалізується певна стратегія вибору правил, пов'язана 3 методом представлення знань в СППР та врахуванням завдання енергозбереження від час керування поїздом.

Підсистема самонавчання забезпечує відбір та запам'ятовування таких прийомів керування локомотивом 3 боку бригади, які забезпечили найменші витрати енергоресурсів на тягу. Інформація від підсистеми навчання поступає на сервер залізниці в метабазу через підсистему керування базою знань. Це забезпечує доступ до оновлених правил всіх бортових СППР. Підсистема керування базою знань $€$ основним інформаційно-перетворюючим елементом системи, що забезпечує доступ інших підсистем до знань та даних.

Нейромережа оцінки складності нештатних ситуацій забезпечує постійний моніторинг обставин руху на предмет безпеки [7] і результатом іiі розрахунків $\epsilon$ параметр, величина якого знаходиться в інтервалі від 0 (небезпека повністю відсутня) до 1 (максимальна небезпека, що гарантовано призведе до транспортної подіi). Вона враховує широкий спектр факторів, що впливають на безпеку руху: технічний стан локомотива, поточна швидкість і відстань до світлофору, умови навколишнього середовища, характеристики поїзда та ефективність гальм, психо-фізіологічні характеристики локомотивної бригади, поточний час доби, наявність обмежень швидкості на ділянці i багато інших кількісних та якісних показників. 


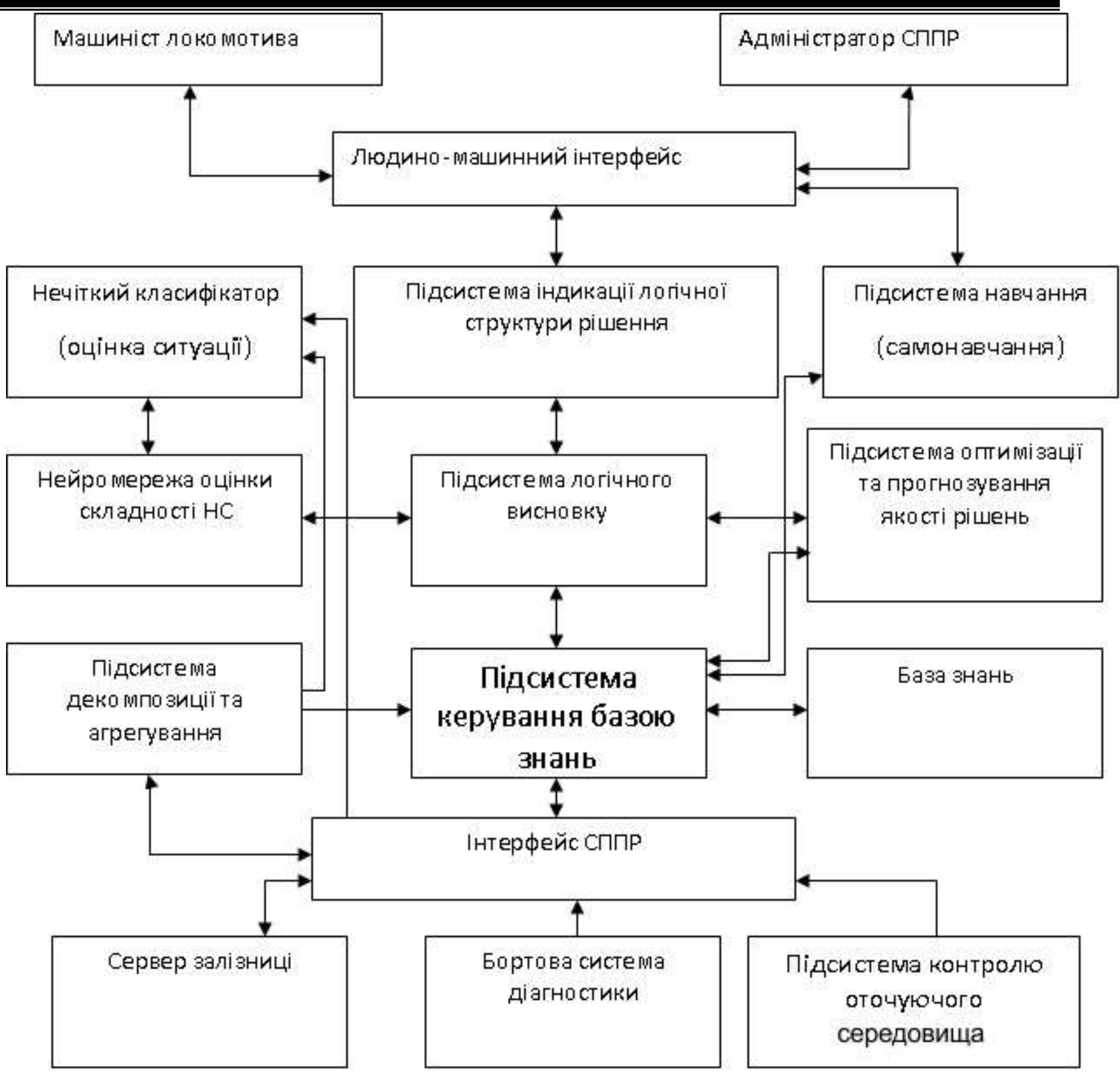

Рис. 3. Структура бортової локомотивної СППР

Висновки. В роботі визначено етапи синтезу структури СППР для локомотивних бригад. Використовуючи ці етапи створено конструкцію розподіленої системи, що дозволить підвищити ефективність експлуатації локомотивів за рахунок визначення та збереження в базі знань найраціональніших прийомів керування.
Під час ведення поїзду машиністу пропонується застосувати визначений режим, що найкраще відповідає поточним значенням профілю колії, маси складу, показанням світлофорів, погодним умовам та ін. Особливістю даної структури є наявність блока, що оцінюе поточний ступінь складності нештатної ситуації, що дає змогу виробляти рішення не тільки 3 позиції раціональності та зниження енерговитрат, але i враховувати вплив реалізації цих рішень на безпеку руху. 


\section{Список використаних джерел}

1. Russel, S. Artificial Intelligence. A Modern Approach. Second edition / S. Russel, P. Norvig. — New Jersey: Prentice Hall, 2003. — 1408 p.

2 Геловани В. Л. Интеллектуальные системы поддержки принятия решений в нештатных ситуациях с использованием информации о состоянии природной среды. / В. Л. Геловани, А. А. Башлыков, В. Б.Бритков, Е. Д. Вязилов. - М.: Эдиториал УРСС, 2001. - 304 c.

3 Мелихов А.Н. Ситуационные советующие системы с нечеткой логикой. / А.Н. Мелихов, Л.С. Берштейн, С.Я. Коровин. - М.: Наука. Гл. ред. физ.-мат.лит., 1990. - 272 с.

4. Роттштейн А. П. Нечеткая надежность алгоритмических процессов. / А. П. Роттштейн, С. Д. Штовба - Винница:Континент, 1997. - 142 с.

5. Тарасов В.А. Интеллектуальные системы поддержки принятия решений. Теория, синтез, эффективность. / В.А. Тарасов, Б. М. Герасимов, И. А. Левин, В. А. Корнейчук. К.:МАКНС, 2007. - $336 \mathrm{c.}$

6. Цвиркун А. Д. Основы синтеза структуры сложных систем. / А. Д. Цвиркун М.:Наука, 1982. - 200 с.

7. Горобченко О. М Формалізація задачі поточної оцінки безпеки руху при управлінні локомотивом / О. М. Горобченко. // Збірник наукових праць Державного економікотехнологічного університету транспорту Міністерства освіти і науки України: Серія «Транспортні системи і технології». - Вип. 24. - К.: ДЕТУТ, 2014. - С. 214-221

Бабанін Олександр Борисович, докт. техн. наук, проф. кафедри «Експлуатація та ремонт рухомого складу» Украӥнський державний університет залізничного транспорту

Ломотько Денис Вікторович, докт. техн. наук, проф. кафедри «УВКР» Украйнський державний університет залізничного транспорту

Горобченко Олександр Миколайович, канд. техн. наук, доцент, докторант кафедри «Експлуатація та ремонт рухомого складу» Украӥнський державний університет залізничного транспорту, тел. +380635802713 ел.nowma superteacher@yandex.ru

Babanin Aleksandr, Doct. of techn. sciences, prof. department "Maintenance and repair of rolling stock", Ukrainian State University of Railway Transport

Lomotko Denis, Doct. of techn. sciences, prof. department "MLKW", Ukrainian State University of Railway Transport

Gorobchenko Aleksandr, PhD, department "Maintenance and repair of rolling stock", Ukrainian State University of Railway Transport, tel.+380635802713, e. mail superteacher@yandex.ru

Стаття постуиила 21.04.2015 